\title{
Trends in HIV prevalence, sexual and health seeking behaviors, and HIV-related discrimination among Nigerian youth
}

Population Council

Follow this and additional works at: https://knowledgecommons.popcouncil.org/departments_sbsr-hiv

Part of the Demography, Population, and Ecology Commons, Family, Life Course, and Society Commons, International Public Health Commons, Maternal and Child Health Commons, and the Medicine and Health Commons

How does access to this work benefit you? Let us know!

\section{Recommended Citation}

Population Council. 2015. "Trends in HIV prevalence, sexual and health seeking behaviors, and HIV-related discrimination among Nigerian youth." Abuja: Population Council. 
$\frac{+2}{8}$

\section{TRENDS IN HIV PREVALENCE,} SEXUAL AND HEALTH SEEKING BEHAVIORS, AND HIV-RELATED DISCRIMINATION AMONG 


\section{Prouration}

Ideas. Evidence. Impact.

The Population Council confronts critical health and development issues-from stopping the spread of HIV to improving reproductive health and ensuring that young people lead full and productive lives. Through biomedical, social science, and public health research in 50 countries, we work with our partners to deliver solutions that lead to more effective policies, programs, and technologies that improve lives around the world. Established in 1952 and headquartered in New York, the Council is a nongovernmental, nonprofit organization governed by an international board of trustees.

Population Council

No. 16 Mafemi Crescent

Abuja

Nigeria

Tel: +23498706071; +23498706057; +2348067787750

email: info.nigeria@popcouncil.org

popcouncil.org

Suggested citation: Population Council. 2015. "Trends in HIV prevalence, sexual and health seeking behaviors, and HIV-related discrimination among Nigerian youth." Abuja, Nigeria: Population Council.

(C2015 Population Council, Inc.

\section{Acknowledgments}

This publication was developed by the Population Council through a project funded by the Ford Foundation. We dedicate this work to Nigerian youth and to the goal of HIV prevention and impact mitigation among youth in Nigeria and beyond. 


\section{Table of Contents}

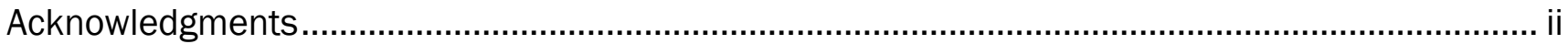

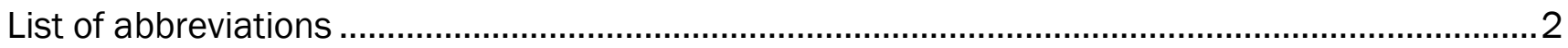

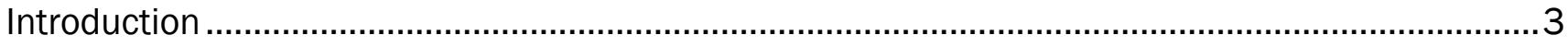

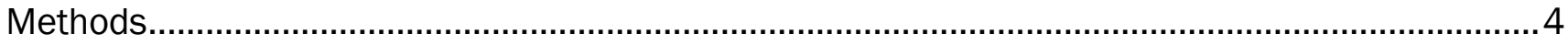

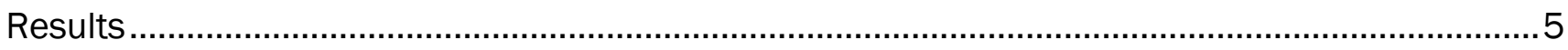

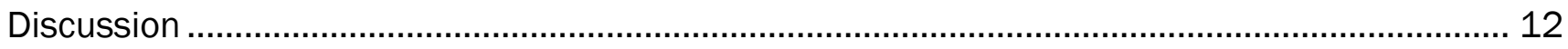

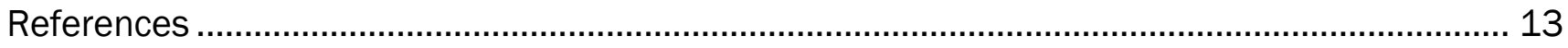




\title{
List of Abbreviations
}

\author{
AYP adolescent and young people \\ NACA National Agency for the Control of AIDS \\ NARHS National HIV\&AIDS and Reproductive Health Surveys \\ PLHIV people living with HIV \\ VCT voluntary counseling and testing
}




\section{Introduction}

Nigeria, a country home to over 170 million people, has a disproportionately heavy youth population of 31.7 percent (10-24 year olds) [1,2] with their well-being intricately tied to the country's prospects for sustainable development. [3] Nigeria is currently facing a mixed HIV epidemic with an HIV prevalence of 3.4 percent which translates into the second highest number of infections in the world. [4] The HIV prevalence among 15-24 year old men and women is 2.5 percent and 3.1 percent respectively. [4] In 2013, it was estimated that 160,000 adolescents (aged 10-19) in Nigeria were living with HIV. [5]

Many Nigerians are exposed to significant reproductive and sexual health risks and their sequelae while young. According to the 2013 Nigeria Demographic and Health Survey, 51 percent of women aged 20-24 and 18.6 percent of their male counterparts reported having sexual intercourse by age 18. [6] Multiple sexual partnerships were reported by 4 percent of young men and 1 percent of young women aged 15-24 years. [6] Additionally, sexually active young men (61.1 percent) and women (43.1 percent) (aged 15-24) also reported relatively low levels of condom use at last non-marital sex [4] and the proportion of young men and women who had ever been tested for HIV and received their test results was 9.1 percent and 15.8 percent respectively. [6]

Despite their obvious vulnerability to HIV infection and the fact that trends and patterns of HIV prevalence among young people tend to significantly shape overall trends in new infections, Nigerian youth remain a neglected subpopulation in the Nigerian HIV response. Although Nigeria has developed a national HIV strategic plan that forms a basis for the HIV response, national AIDS and related policies contain very few youth-centered provisions. [7] Overall, the national strategic plan targets youth as part of the general population. In order to fill this gap and heighten its focus on the youth, the National Agency for the Control of AIDS (NACA) is currently developing the first National HIV Strategy for Adolescent and Young People (AYP). A trend analysis of HIV prevalence, sexual and health seeking behaviors, and HIV-related discrimination among youth would provide information that policy-makers and program planners/managers can utilize to plan, design, allocate resources to, monitor, and evaluate policies and programs that effectively address the HIV prevention and impact mitigation needs (including stigma and discrimination) of youth in Nigeria. 


\section{Methods}

Secondary analysis was conducted on youth (aged 15-24 years) data from five consecutive National HIV\&AIDS and Reproductive Health Surveys (NARHS 2003, 2005, 2007 and 2012). The objectives of the surveys were to obtain accurate HIV prevalence estimates and information on behavioural and other risk factors related to HIV infection at the national, zonal and to some extent the state levels, to provide information on the situation of reproductive and sexual health and its determinants in Nigeria, to provide data for the assessment of the impact of on-going family planning and HIV/ AIDS behaviour change interventions, as well as to provide insights into existing gaps for its effectiveness.

Analysis was conducted using chi-square test to assess the trend in prevalence of indicators of interest across the five survey years for both males and females respectively. 


\section{Results}

\section{HIV PREVALENCE}

Since 2007, there has been a marginal but statistically insignificant increase in HIV prevalence for both young men (1.9 percent to 2.5 percent; $p=0.155$ ) and young women ( 2.9 percent to 3.1 percent; $p=0.618$ ).

TABLE 1 HIV prevalence among Nigerian youth

\begin{tabular}{lccccc}
\hline & 2003 & 2005 & 2007 & 2012 & p-value \\
& $\%(95 \% \mathrm{Cl})$ & $\%(95 \% \mathrm{Cl})$ & $\%(95 \% \mathrm{Cl})$ & $\%(95 \% \mathrm{Cl})$ & \\
\hline Male & - & - & $1.9(1.3-2.5)$ & $2.5(2.0-3.1)$ & 0.155 \\
Female & - & - & $2.9(2.1-3.7)$ & $3.1(2.6-3.7)$ & 0.618 \\
\hline
\end{tabular}

Additionally, the proportion of young Nigerian men and women who felt they were not at risk of HIV infection has significantly declined between 2003 and 2012 (60.2 percent to 46.8 percent and 61.5 percent to 40.9 percent) respectively $(p<0.0001)$. This may be due to the increased levels of HIV education programs in the country over this time period.

\section{TABLE 2 HIV risk perception among Nigerian youth}

\begin{tabular}{|c|c|c|c|c|c|}
\hline $\begin{array}{l}\text { Percentage of } \\
\text { young men } \\
\text { and women } \\
\text { who did not } \\
\text { feel at risk for } \\
\text { HIV infection }\end{array}$ & $\begin{array}{c}2003 \\
\%(95 \% \mathrm{Cl})\end{array}$ & $\begin{array}{c}2005 \\
\%(95 \% \mathrm{Cl})\end{array}$ & $\begin{array}{c}2007 \\
\%(95 \% \mathrm{Cl})\end{array}$ & $\begin{array}{c}2012 \\
\%(95 \% \mathrm{Cl})\end{array}$ & $\mathrm{p}$-value \\
\hline Male & $60.2(56.0-62.5)$ & $65.4(64.4-66.4)$ & $57.5(55.5-59.5)$ & $46.8(45.3-48.3)$ & 0.000 \\
\hline Female & $61.5(59.5-63.5)$ & $60.4(59.4-61.4)$ & $56.1(54.1-58.2)$ & $40.9(39.6-42.2)$ & 0.000 \\
\hline
\end{tabular}

\section{RISKY SEXUAL BEHAVIORS}

Age at first sex is an important indicator of sexual risk because it determines the duration of exposure to sexually transmitted infections including HIV. From 2003-2012, there was a significant decline in the proportion of young women (16.6 percent to 9.2 percent) and men (6.0 percent to 4.5 percent) reporting sexual debut before age 15 $(p<0.01)$. Nonetheless, there still remains a higher proportion of young women than young men in Nigeria reporting sexual debut at or before the age of 15. 


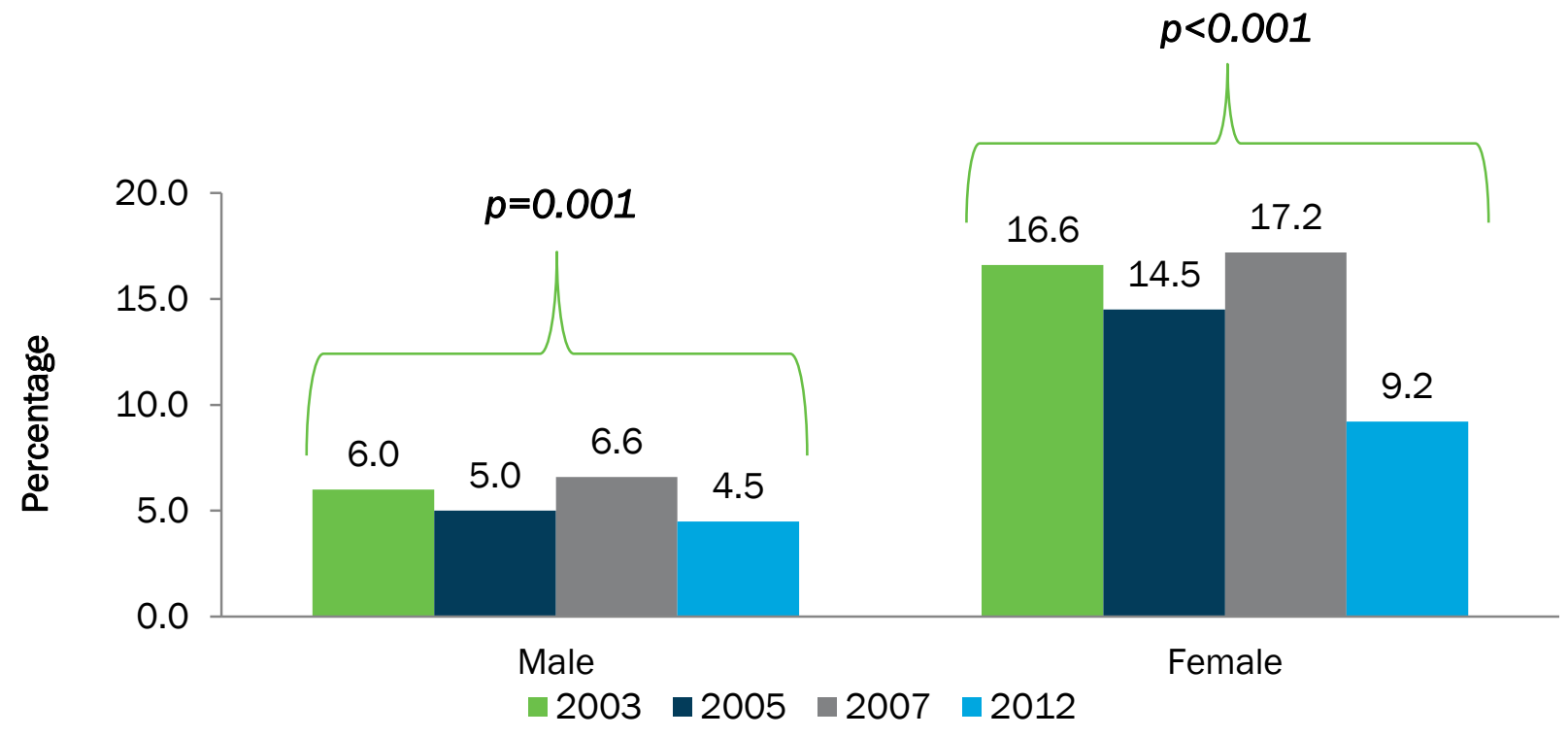

However a study among young men in rural South Africa found that, compared to their female counterparts, young men reporting sexual debut before age 15 were more likely not to use condoms at first sex and more likely to have had multiple and casual sexual partners. [8]

\section{MULTIPLE SEXUAL PARTNERSHIPS}

In line with societal gender norms, self-reporting of multiple sexual partnerships has been relatively low among sexually active females and relatively high among sexually active males. In this study, there has been a marginal decrease in the proportion of young men reporting multiple sexual partnerships (11.1 percent to 9.8 percent) unlike among young women where reports of multiple sexual partnerships has increased ( 2.3 percent to 3.4 percent) although these changes are not statistically significant. Young men's higher reporting of multiple sexual partnerships may be due to peer/societal pressure to demonstrate masculinity through sexual experience or prowess. $[9,10]$ 


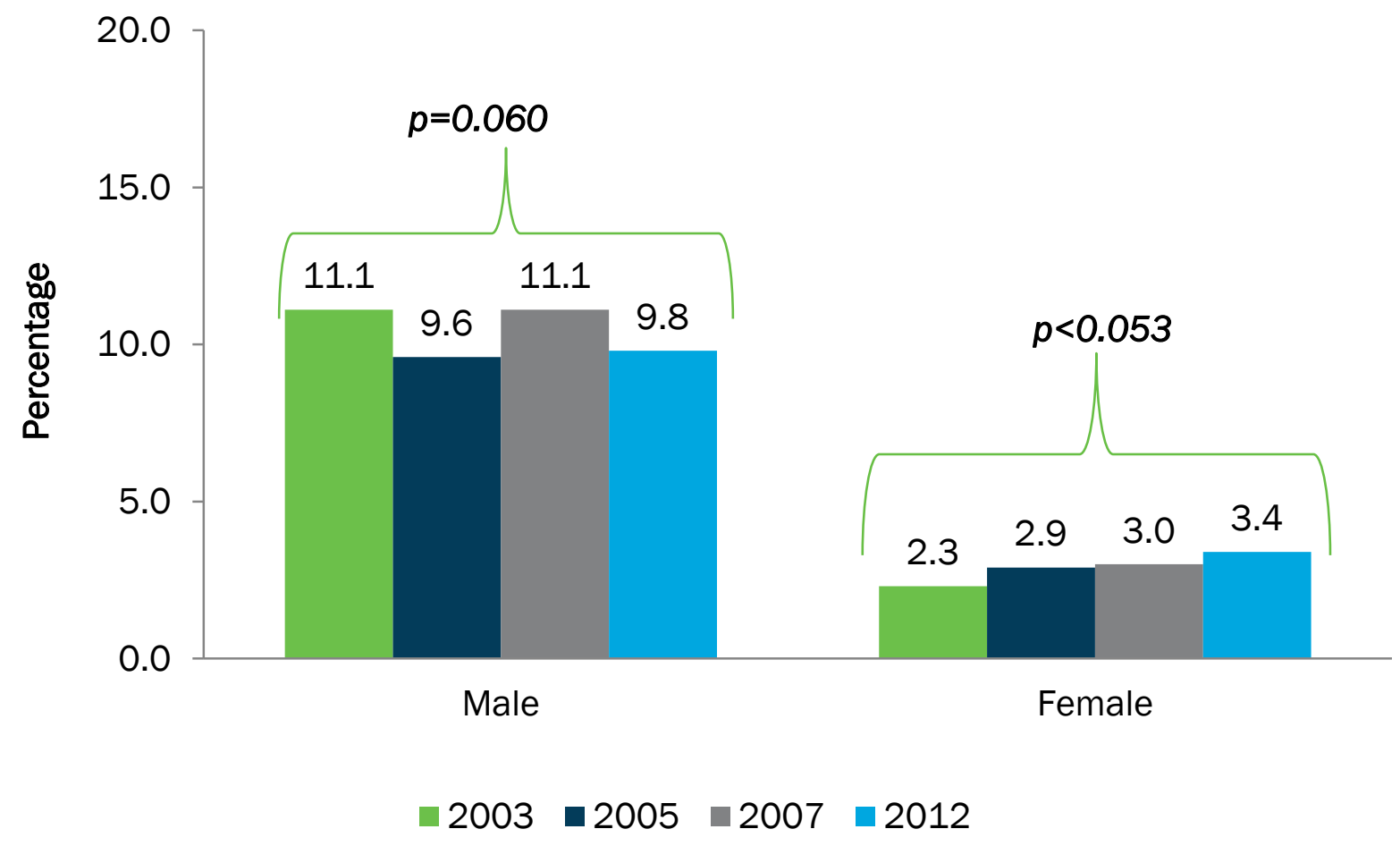

\section{SEXUAL HEALTH-SEEKING BEHAVIORS}

\section{Condom use}

Condom use has remained relatively low although the proportion of young men and women reporting condom use at last non-marital sex has slightly increased from 2003 to 2012 (male: 58.6 percent to 61.1 percent female: 39.5 percent to 43.1 percent). Consistently a greater number of young men than women reported condom use at last non-marital sex in each survey year.

Reasons given nonuse of condoms with sexual partners were shyness, fear of implying a lack of trust in their sexual partner, and concerns about their reputation in the eyes of their partners, parents, or society. [11,12] Lack of knowledge of correct use of condoms is also another possibility as revealed by a study conducted by Lawoyin among 18-30 year old women in Ibadan and Lagos. Only 35.3 percent of the young women surveyed knew how to use a condom correctly. [13] Adedimeji et al, in their study of young urban slum inhabitants (15-24), found that among girls/young women, those who perceived social support from peers and non-parental figures were more likely to use condoms; while among boys/young men, earning an income, high risk perception and self-efficacy were associated with higher odds of condom use. [14]

The low level of condom use among Nigerian youth is particularly worrisome given the relatively high levels of highrisk sexual behavior they engage in. Increased condom messaging and distribution, and the inclusion of condom/sexual negotiation skills in youth sexuality education/HIV prevention programs, are essential. 
Figure 3 Proportions of young men and women reporting condom use at last non-marital sex

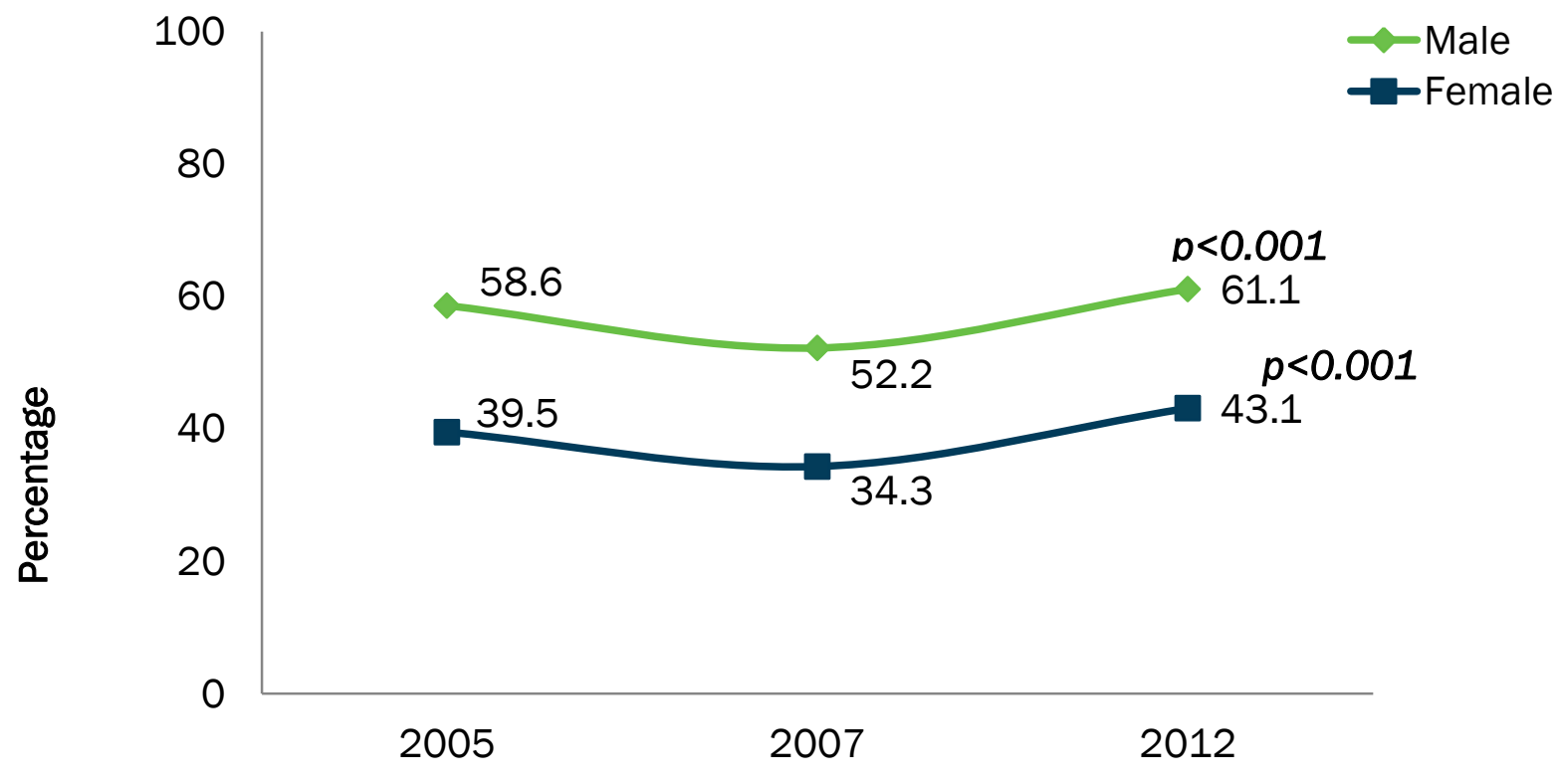

\section{Uptake of HIV testing}

Willingness to take an HIV test and ever had an HIV test have both increased significantly for young men and women through the study period although higher among men than women.

Figure 4 Percentage of young men and women (never been tested) that are willing to have an HIV test

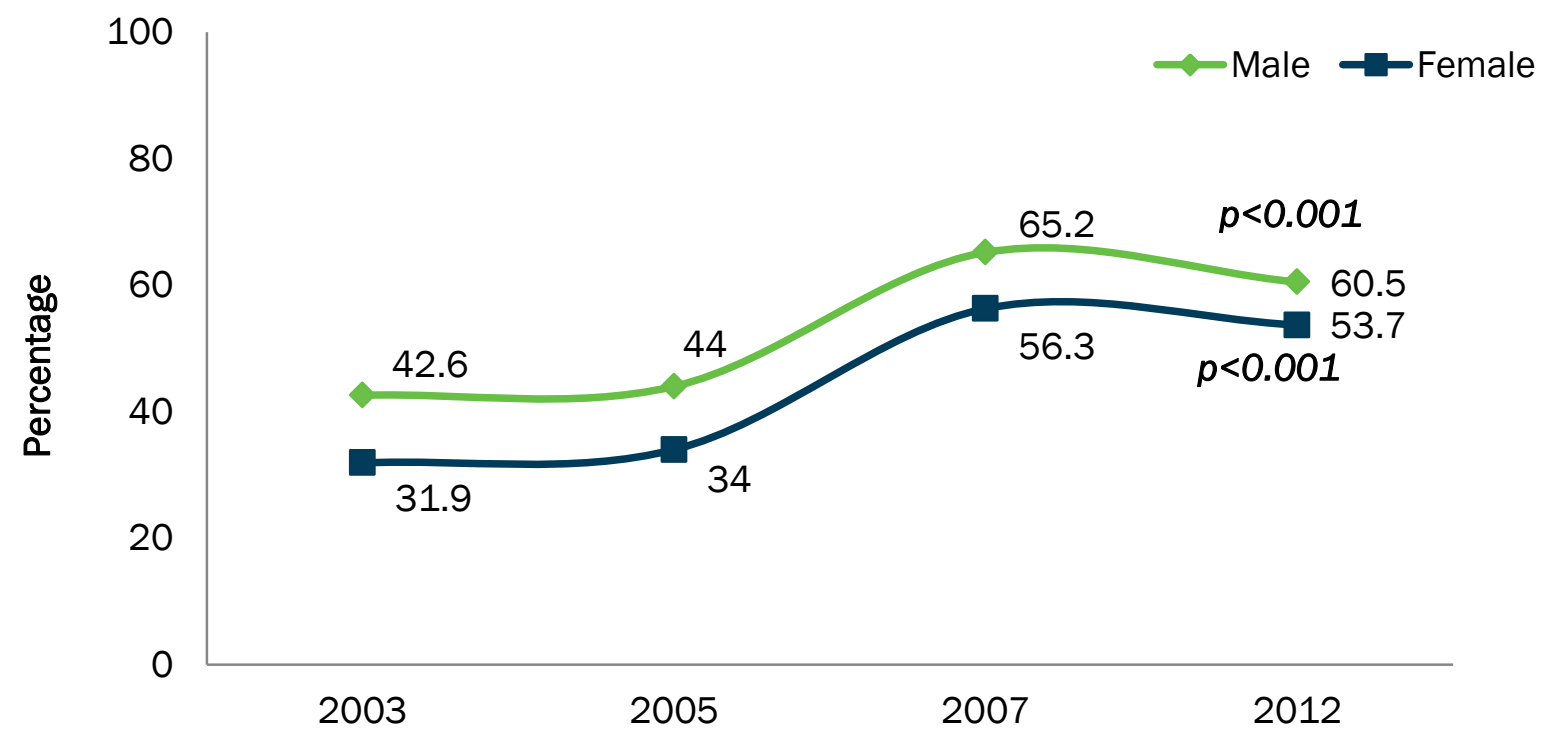

The proportion of young men willing to have an HIV test has increased from 42.6 percent in 2003 to 60.5 percent in 2012 and that for young women from 31.9 percent to 53.7 percent. 


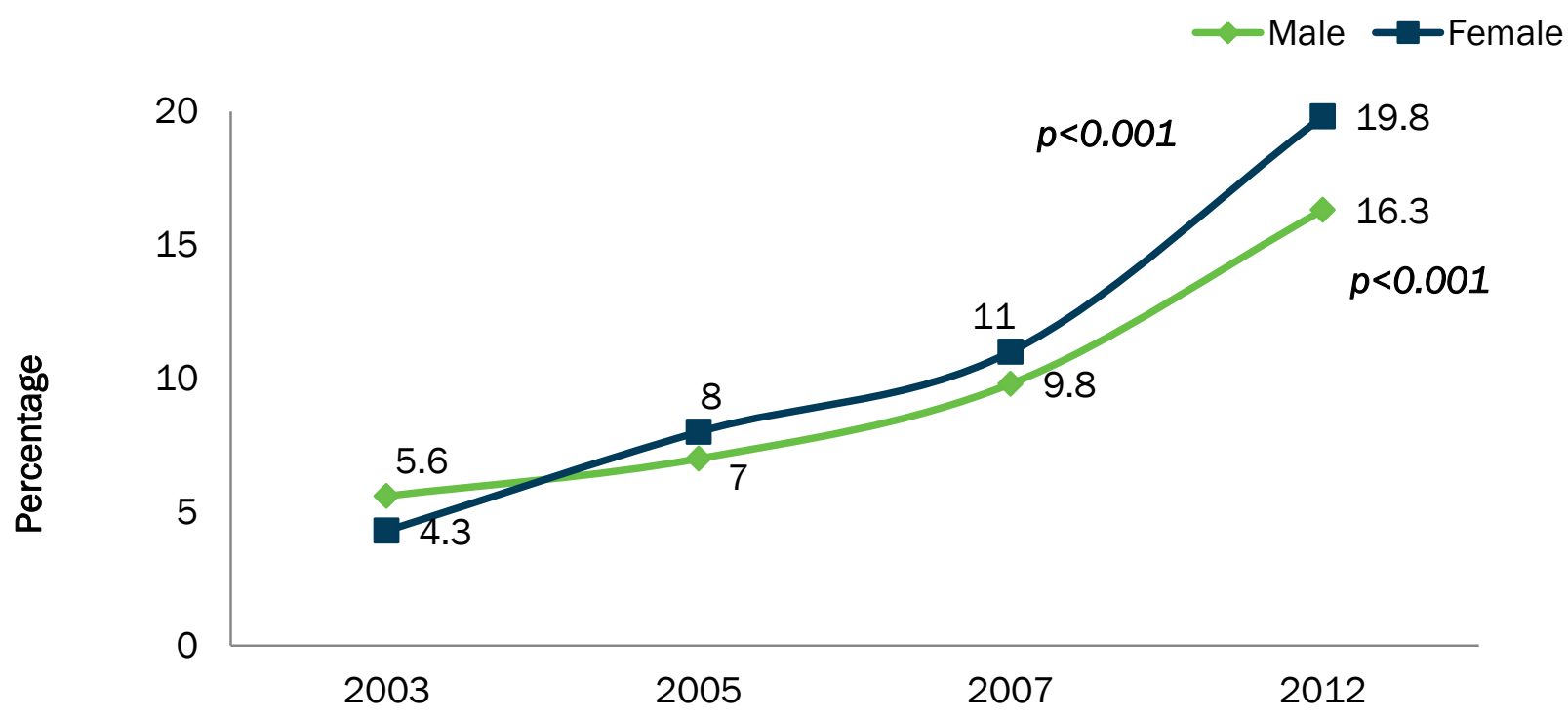

The proportion of young persons who reported ever having an HIV test increased from 5.6 percent to 16.3 percent for men and from 4.3 percent to 19.8 percent for women. Despite this improvement, uptake of HIV testing among young people in Nigeria remains relatively low.

Factors that may contribute to the low uptake of voluntary counseling and testing (VCT) among youth are low awareness of VCT and of places where VCT services are offered, low HIV risk perception, concerns about confidentiality, actual or perceived cost of VCT, fear of being positive, and stigmatization. $[15,16]$ Another barrier to testing might be the requirement for parental consent to test youth below 18 years which is the legal age of consent for access to HIV testing.

The slight disparity between males and females with regard to uptake of VCT may be because pregnancy affords young women access to maternal/child services such as antenatal care, where VCT is one of several services provided. An additional factor may be men's poorer health-seeking behavior that results from gender norms that feminize illness and the seeking of formal medical care. [17] Given the higher levels of self-reported high-risk behavior among young men, it is important for HIV prevention program designers and implementers to target interventions, especially VCT services, toward men, and to explore ways to increase male uptake of HIV services in general.

\section{COMPREHENSIVE HIV KNOWLEDGE}

According to the composite of the five UNGASS indicators ${ }^{1}$ for HIV knowledge, comprehensive knowledge of HIV has increased slightly but remains worrisomely low among young Nigerian men (28.3 percent to 32.8 percent) and women (18.2 percent to 27.1 percent). Generally, more young men demonstrate higher comprehensive knowledge of HIV than young women.

\footnotetext{
${ }^{1}$ Comprehensive knowledge" refers to knowing that consistent use of condoms during sexual intercourse and that having just one HIV-negative, faithful partner can reduce the chances of becoming infected with HIV; knowing that a healthy-looking person can have HIV; and rejecting the two most common local misconceptions about HIV transmission and prevention.
} 
Figure 6 Percentage of young men and women reporting correct answers to all five indicators of HIV knowledge

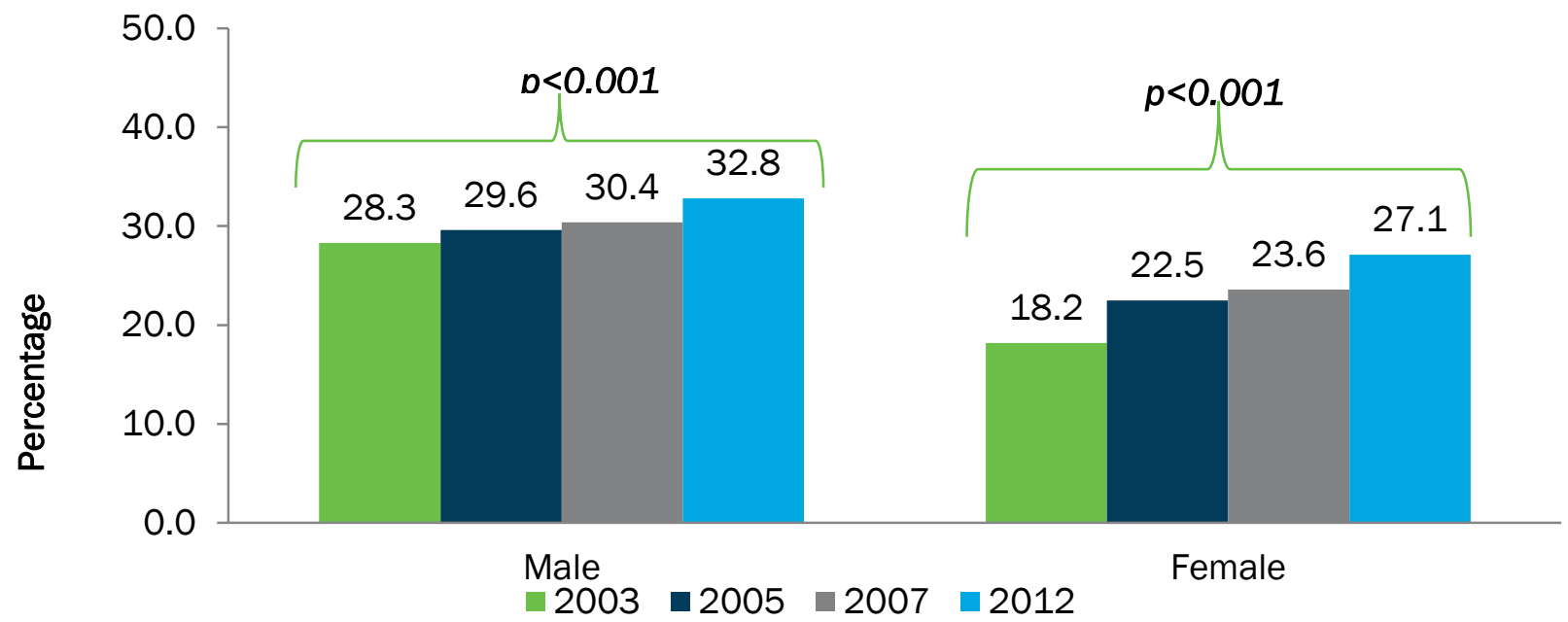

\section{STIGMA AND DISCRIMINATION}

According to UNAIDS, [18] HIV/AIDS-related stigma can be described as a "process of devaluation" of people either living with or associated with HIV/AIDS, whereas discrimination follows stigma and is the unfair and unjust treatment of an individual based on his or her real or perceived HIV status. Stigma and discrimination breach fundamental human rights and can occur at a number of different levels, including economic, institutional, political, psychological, and social levels.

HIV stigma remains very high among young Nigerians though the levels of accepting attitudes towards people living with HIV (PLHIV) has increased slightly among men (3.6 percent to 9.1 percent) and women (3.0 percent to 7.8 percent). This is concerning as stigma and discrimination play an enormous role in facilitating the spread of HIV by weakening prevention efforts, because fear of stigma and discrimination are the main reasons individuals refuse to be tested, disclose their sero-status, or take antiretroviral drugs.

Figure 7 Percentage of young men and women with accepting attitudes towards PLHIV\#

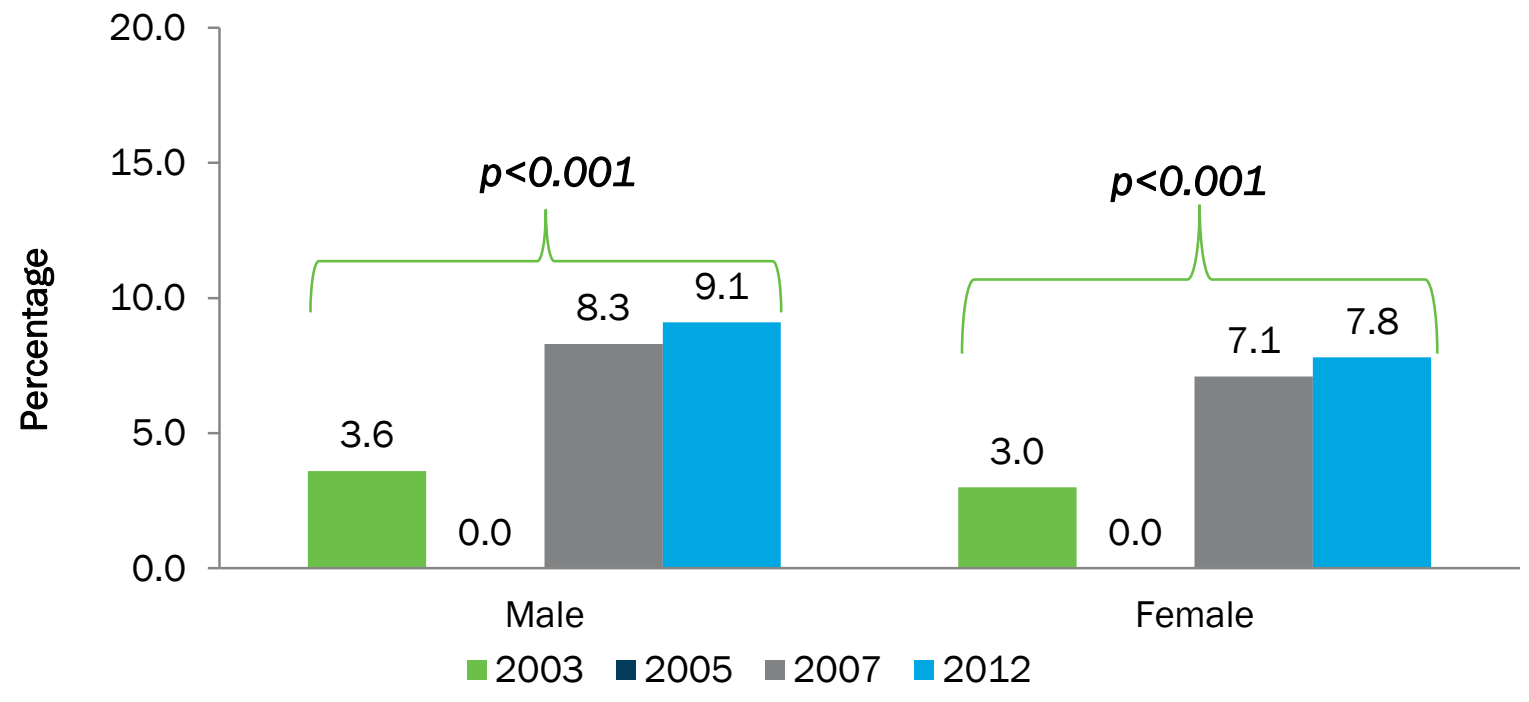


\#\#"Accepting attitudes to PLHIV" refers to being willing to care for a member of your family who is sick with the HIV virus in your household; being willing to buy fresh vegetables from a shopkeeper or food seller that has the HIV virus; believing that a female teacher who has the HIV virus but is not sick should be allowed to continue teaching in school and not wanting to keep secret the fact that a family member has been infected with the HIV virus. 


\section{Discussion}

The picture for young Nigerians in terms of their HIV-related risky and health-seeking behaviors is mixed. At first glance, there has been a slight but statistically insignificant increase in HIV prevalence. At the same time, there have also been appreciable increases in levels of HIV risk perception, condom use at last marital sex, willingness to have an HIV test, ever had an HIV test, comprehensive knowledge of HIV, and accepting attitudes of PLHIV. There has also been a significant decline in levels of sexual debut before age 15 during the study period of 2003-2012. However, further assessments reveal that levels of health seeking behaviors and accepting attitudes towards PLHIV still remain poor and gender-related differences are found in some indicators (multiple sexual partnerships, ever had an HIV test, condom use at last non-marital sex, comprehensive HIV knowledge).

The low level of comprehensive HIV knowledge is a cause for alarm with less than two-fifths of young people having comprehensive HIV knowledge. The health belief model is based on the principle that there is a relationship between beliefs, attitudes, and behaviours. [19] Knowledge affects beliefs and perceptions which in turn influences behaviors. This fact underlies most HIV prevention programs focusing on improving HIV knowledge. According to the UNAIDS business case for youth, at least 80 percent of youth in and out of school are expected to have comprehensive HIV knowledge. [20] Unfortunately, Nigeria is nowhere close to achieving this indicator.

Condom use at last non-marital sex was reported by less than half of young women and only by about three-fifths of young men. Less than one-fifth of young Nigerians, have ever had an HIV test yet over half of those who have never been tested desire to have an HIV test. Less than 10 percent of young Nigerians expressed accepting attitudes towards PLHIV.

Clearly, more interventions that are evidence-based and can be scaled up need to be implemented to adequately cater to the unique HIV vulnerabilities of young Nigerians. Improving comprehensive HIV knowledge and sexualhealth seeking behaviors especially uptake of VCT and condom use by male and female youth is imperative.

\section{RECOMMENDATIONS}

The following recommendations are proffered based on the results of these analyses:

- Improving sexual-health-seeking behaviors, especially uptake of VCT by male youth and condom use by female youth through tailored interventions is essential.

- Evidence-based advocacy targeted at policymakers and donors to increase and sustain the attention to youth HIV \& AIDS vulnerabilities needs to be maintained.

- The National Agency for the Control of AIDS must continue to fulfill its oversight function in ensuring that youth are not neglected in national HIV policies and programs.

- Efforts to promote the mainstreaming of youth-friendly sexual and reproductive health and HIV services are required to improve the reach of such services among the youth population.

- Stigma-reduction interventions need to be tailored and targeted at Nigerian youth. 


\section{References}

1. National Population Commissiaon. 2009. 2006 Population and Housing Census of the Federal Republic of Nigeria Priority Tables, Volume 1. Abuja, Nigeria: National Population Commission.

2. United Nations Population Division (UNPD). 2014. World Population Projections, September 2014.

3. United Nations Population Fund (UNFPA). "Factsheet: young people's health and development in Nigeria." Geneva: UNFPA.

4. Federal Ministry of Health [Nigeria]. 2013. National HIV/AIDS and Reproductive Health Survey, 2012 (NARHS Plus II 2012). Federal Ministry of Health Abuja, Nigeria.

5. United Nations Programme on HIV/AIDS (UNAIDS) HIV Estimates, 2013.

6. National Population Commission (NPC) [Nigeria] and ICF Macro. 2013. Nigeria Demographic and Health Survey 2013. Abuja, Nigeria; National Population Commission and ICF Macro.

7. Population Council. 2014. "HIV/AIDS vulnerabilities, discrimination, and service accessibility among Nigeria's youth." Abuja, Nigeria: Population Council.

8. Harrison A., J. Cleland, E. Gouws, and J. Frohlich. 2005. "Early sexual debut among young men in rural South Africa: Heightened vulnerability to sexual risk," Sexually Transmitted Infections 81: 259-261.

9. Varga, C.A. 2001. "The forgotten fifty percent: A review of sexual and reproductive health research and programs focused on boys and young men in sub-Saharan Africa," African Journal of Reproductive Health 5(3): 175-195.

10. Izugbara, C. O. (2008). "Masculinity scripts and abstinence-related beliefs of rural Nigerian male youth," Journal of Sex Research 45(3): 262-276.

11. Adedimeji, A.A., F.O. Omololu, O. Odutolu. 2007. "HIV risk perception and constraints to protective behaviour among young slum dwellers in Ibadan, Nigeria," Journal of Health, Population, and Nutrition 25(2): 146-157

12. Owolabi, A., A. Onayade, I. Ogunsola, et al. 2005. "Sexual behaviour of secondary school adolescents in llesa, Nigeria: Implications for the spread of STIs including HIV/AIDS," Journal of Obstetrics and Gynaecology 25(2): 174-178.

13. Lawoyin, O.O.C. 2007. "Findings from an HIV/AIDS programme for young women in two Nigerian cities: a short report," Afr J Reprod Health 11(2):99-106.

14. Adedimeji, A. A., Heard, N. J., Odutolu, O., \& Omololu, F. O. 2008. "Social factors, social support and condom use behaviour among young urban slum inhabitants in southwest Nigeria," East African Journal of Public Health 5(3): 215-222.

15. Yahaya, L.A., A.A.G. Jimoh, and O.R. Balogun. 2010. "Factors hindering acceptance of HIV/AIDS voluntary counselling and testing (VCT) among youths in Kwara State, Nigeria," Journal of AIDS and HIV Research 2(7): 138-143.

16. Ikechebelu, I.J., G.O. Udigwe, N. Ikechebelu, and L.C. Imoh. 2006. "The knowledge, attitude and practice of voluntary counselling and testing (VCT) for HIV/AIDS among undergraduates in a polytechnic in southeast, Nigeria," Nigerian Journal of Medicine 15(3): 245-249

17. Myburgh, H. 2011. The clinic as a gendered space: Masculinities, health-seeking behavior, and HIV \&AIDS. $<$ http://www.consultancyafrica.com/index.php?option=com_content\&view=article\&id=760:the-clinic-as-agendered-space-masculinities-health-seeking-behaviour-and-hiv-a-aids\&catid=61:hiv-aids-discussionpapers\&ltemid=268>. Accessed May 2015.

18. Joint United Nations Programme on HIV/AIDS (UNAIDS). 2003. Stigma and Discrimination Factsheet. <http://data.unaids.org/publications/Fact-Sheets03/fs_stigma_discrimination_en.pdf>. Accessed May 2015.

19. Azjen, I. and M. Fishbein. 1980. Understanding and Predicting Social Behavior. Englewood Cliffs, NJ: Prentice Hall.

20. UNAIDS. 2010. "We can empower young people to protect themselves from HIV." Joint action for results, UNAIDS outcome framework: Business case 2009-2011." Geneva: UNAIDS. 


\section{Appendix I: List of Contributors}

Ayodeji Oginni

Otibho Obianwu

Sherry Hutchinson

Sylvia Adebajo 
Population Council No. 16 Mafemi Crescent Abuja, Nigeria

Ideas. Evidence. Impact. 